\title{
Performance of Ceriporiopsis sp. in the Treatment of Black Liquor Wastewater
}

\section{Unjuk Kerja Ceriporiopsis sp. dalam Pengolahan Air Limbah Lindi Hitam}

\author{
Ajeng Arum Sari*, Feni Amriani, dan R. Irni Fitria Anggraini \\ Research Center for Chemistry, Indonesian Institute of Sciences, \\ Kawasan Puspiptek Serpong, Tangerang Selatan, Indonesia 15314 \\ ${ }^{*}$ Corresponding author: +62-21-7560929/+62-21-7560549 \\ ajeng_as@yahoo.co.id
}

\begin{abstract}
ABSTRAK
Produksi bioetanol dari tandan kosong kelapa sawit menghasilkan air limbah lindi hitam dalam jumlah yang banyak. Lindi hitam ini mengandung $\mathrm{NaOH}$ sehingga dengan demikian bersifat toksik pada ekosistem perairan jika dibuang langsung ke lingkungan. Saat ini air limbah lindi hitam telah diolah dengan menggunakan metode koagulasi, akan tetapi tetap membutuhkan pengolahan lanjutan. Penelitian ini bertujuan untuk menentukan kemampuan jamur pelapuk putih dalam mendegradasi air limbah lindi hitam. Lima jamur pelapuk putih diuji kemampuannya untuk mendekolorisasi lindi hitam di media agar dan cair. Dua jamur, Ceriporiopsis sp. dan Phanerochaete chrysosporium, mampu tumbuh lebih dari 50\% di media agar. Lindi hitam dengan dan tanpa koagulasi pada konsentrasi 15000 ppm mampu disisihkan sebesar 70-89\% pada hari ke-30i. Unjuk kerja Ceriporiopsis sp. dievaluasi dalam kaitannya dengan mendekolorisasi lindi hitam, menyisihkan COD, dan berat kering miselia pada air limbah lindi hitam dengan dan tanpa koagulasi. Warna lindi hitam dengan dan tanpa koagulasi dapat disisihkan masing-masing hingga 90,13 dan 86,65\%. COD dapat disisihkan hingga 70,17 dan 40,09\% masing-masing dalam lindi hitam dengan dan tanpa koagulasi. Koagulan PAC menghambat degradasi lindi hitam oleh jamur pelapuk putih. Hasil penelitian ini menunjukkan bahwa Ceriporiopsis sp. berpotensi untuk digunakan sebagai pendegradasi air limbah lindi hitam.
\end{abstract}

Kata Kunci: Bioetanol generasi dua; lindi hitam; dekolorisasi; koagulasi; Ceriperiopsis sp.; pengolahan air limbah

\begin{abstract}
High amount of black liquor wastewater is generated from bioethanol production by using oil palm empty fruit bunches. It contains an alkaline solution $(\mathrm{NaOH})$, so it is quite toxic for aquatic ecosystems if discharged directly into waters. Actually, black liquor has been treated by coagulation method, but it still needs additional treatment. The aim of this study is to determine the degradation of black liquor wastewater by selected white-rot fungi (WRF). Five different strains of WRF have been tested for their ability to decolorize black liquor on agar and liquid media. Two of five fungi studied, Ceriporiopsis sp. and Phanerochaete chrysosporium, showed their capacity to grow more than $50 \%$ on agar medium. In liquid medium, the percentage of decolorization of $15,000 \mathrm{ppm}$ coagulated and diluted black liquor varied from 70 to $89 \%$ at day 30 depending on the fungal strain. Ceriporiopsis sp. showed the better ability to decolorize black liquor than P. chrysosporium. The performance of Ceriporiopsis $\mathrm{sp}$ was evaluated in terms of decolorization of black liquor as well as reduction of chemical oxygen demand (COD) and mycelial dry weight, both in original and coagulated black liquor. The color of original and coagulated black liquor can be decolorized up to 90.13 and $86.85 \%$, respectively. Whereas, COD was reduced up to 70.17 and $40.09 \%$ in original and coagulated black liquor, respectively. The presence of Poly Aluminum Chloride (PAC) coagulant inhibited degradation of black liquor by fungus. The result demonstrated that Ceriporiopsis sp has a potential alternative to treat black liquor wastewater.
\end{abstract}

Keyword: Bioethanol second generation; black liquor; decolorization; coagulation; Ceriporiopsis sp; wastewater treatment 


\section{INTRODUCTION}

Bioethanol has been produced since the 1970's and then there has been a dramatic increase in bioethanol production based on sugar and vegetable. Unfortunately, this development has attracted criticism because of competition with food availability, actual net energy output, limitation land-use, and the high production cost $^{(1)}$. A solution to this problem is to explore alternative feedstocks such as lignocellulosic biomass, known as second-generation bioethanol.

One lignocellulosic waste that is available in abundance in Indonesia is oil palm empty fruit bunches (OPEFB). OPEFB was consists of cellulose $(30 \%)$, hemicellulose $(13 \%)$, lignin $(37 \%)$, and others $(20 \%)^{(2)}$.Cellulose is converted for bioethanol production via the action of cellulase enzymes into glucose. The breakdown of OPEFB to glucose monomers is the basis for second-generation bioethanol production (G2). Mainly, cellulose is the main part of bioethanol production. Lignin polymer is highly resistant to breakdown because it is a complex aromatic heteropolymer, composed ofphenylpropanoid aryl-C3 units, linked together via a variety of ether and $\mathrm{C}-\mathrm{C}$ bonds ${ }^{(3)}$.

Bioethanol production from OPEFB consists of three primary processes, which are pretreatment, hydrolysis, and fermentation. It requires large quantities of water especially in pretreatment process using alkali chemical $\mathrm{NaOH}$. This production required $600 \mathrm{~kg}$ of OPEFB and resulted in $76.46 \mathrm{~kg}$ of bioethanol and 3,000 liters of wastewater for pretreatment process, called black liquor. Lignin is the main compound in black liquor ${ }^{(4)}$.

During the production of bioethanol, a wastewater with a high chemical oxygen demand (COD) concentration and also may consist of potentially toxic chlorinated compounds, suspended solids, phenolics, and resin along with lignins is produced ${ }^{(5)}$. The presence of $\mathrm{NaOH}$ impacts high $\mathrm{pH}(10-13)$ to the wastewater, and it causes poorly biodegradable, and only a few microorganisms can degrade it. The discharge of black liquor with base condition into nature without any treatment is difficult to be degraded, harmful to aquatic ecosystems and constitutes a threat to human health through the contamination of drinking water supplies, recreational water or edible organic species ${ }^{(6)}$.

A wastewater treatment is required for black liquor degradation. Coagulation method by using Poly Aluminum Chloride (PAC) has been developed to treat black liquor. The major advantage of chemical treatment is that high removal of color, COD, and TSS before applying biological treatment (aerobic treatment, anaerobic treatment, and fungal treatment) ${ }^{(7,8)}$. Because of its chemicalcomplexity contents, a technology that can treat black liquor wastewater simultaneous is needed. The non-biodegradable organic compound fraction and high molecular weight organic compounds need physical and chemical methods. The soluble biodegradable organic compounds are efficiently removed by biological methods ${ }^{(9)}$. Biological methods especially fungal treatment are important ways to depolymerize lignin.

White-rot fungi (WRF) are the most various wood-rotting organisms, because of their ability to degrade lignin, hemicelluloses, and cellulose.WRF can be one option to degrade black liquor wastewater because these fungi secrete one or more enzymes such as lignin peroxidase, manganese peroxidase, and laccase ${ }^{(10)}$. Since the late 1970s, several studies have demonstrated that black liquor as pulp mill effluents could be decolorized by cultures of WRF. Several WRF such as Phanerochaete chrysosporium, Trametes versicolor, and $T$. elegansare recognized for their ability to degrade lignin and black liquor wastewater ${ }^{(11,12)}$. Decolorization of black liquor from kraft pulping process as $60-90 \%$ was needed by several white rot fungi at 60 days $^{(13)}$. The degradation by using WRF is a promising method for efficient, does not require high cost, minimize sludge formed and applicable ${ }^{(14)}$. Adding coagulant is not only effective to remove black liquor, but also create a more complex structures of black liquor. There is a little information about the ability of WRF to degrade coagulated black liquor from bioethanol process.

In this study, an investigation was conducted to explore the lignin-degrading capacity of attached-growth white-rot fungi. In the screening method, the ability of several WRF to degrade black liquor wastewater was tested on agar medium. In the future, the selected fungi were used to degrade black liquor wastewater in a liquid medium. The ability of WRF to degrade the original black liquor wastewater and the remained black liquor wastewater after coagulation was compared. The removal efficiency of the treatments was determined by monitoring the decrease of color, COD, and dry mycelial weights.

\section{MATERIAL AND METHODS}

\subsection{Organisms}

Five white-rot fungi (WRF) consisted of Volvariella volvacea, Pycnoporus sp., 
Ceriporiopsis sp., Pleurotus ostreatus, and Bjerkandera sp. were collected from Research Center for Chemistry, Indonesian Institute of Sciences. The history oftheir origin came from various areas such as Southeast Asia, East Asia, or northern temperate areas. They were cultured on a malt extract agar medium (malt extract 20 $\mathrm{g} / \mathrm{l}$, glucose $20 \mathrm{~g} / \mathrm{l}$, agar $20 \mathrm{~g} / \mathrm{l}$, and polypeptone 1 $\mathrm{g} / \mathrm{l})$ at $25^{\circ} \mathrm{C}$ for seven days and maintained at low temperature $4^{\circ}$ Cbefore being used.

\subsection{Black liquor wastewater}

Black liquor wastewater was obtained from bioethanol process in pilot plant Research Center for Chemistry, Indonesian Institute of Sciences. The waste liquor formed in the pretreatment process consists of an alkaline aqueous solution that contains organic and inorganic solids and has a distinctive dark coloration. $\mathrm{pH}$ wastewater is 13 , and the color is black. The sample was diluted with distilled water to obtain the concentration of black liquor was 15,000 ppm. Coagulation method to degrade black liquor wastewater was used in our previous experiment $^{(4)}$. Black liquor $1 \%$ was mixed with poly-aluminum chloride (PAC) at $200 \mathrm{rpm}$ for one minute and then mixed at $50 \mathrm{rpm}$ for two minutes. Next, the effluent sample was left steady for 30 minutes for sedimentation. In this experiment, residual coagulation wastewater was used as a medium for fungal growth and as a pollutant which should be degraded by WRF. To study the effects of PAC for fungal growth and its degradation, diluted black liquor wastewater in the same concentration with coagulated wastewater was also used.

\subsection{Decolorization on agar medium}

Growth rates of strains were assessed in micronutrient medium prepared with black liquor wastewater 15,000 ppm. Chemicals used for agar media can be found in the previous study ${ }^{(5)}$. Petri dishes were inoculated in the center with one agar plug ( $7 \mathrm{~mm}$ diam) cut from the cultured fungus. A control plate with no black liquor added was also inoculated with each strain. The inoculated plates were incubated at $25^{\circ} \mathrm{C}$ for five days, and the level of growth was assessed by measuring the radial extension of mycelium. The growth percentage was calculated by measuring the increase disc diameter of each fungus, according to the formula (1):

$\%$ growth $=\left(\frac{\phi c-\phi s}{\phi c}\right) \times 100 \%$ (1)

where:

$\emptyset s=$ fungal diameter in treated sample with black liquor $(\mathrm{cm})$ $\varnothing c=$ fungal diameter in control without black liquor $(\mathrm{cm})$

The fungi chosen for next experiment were fungal with growth more than $50 \%$.

\subsection{Decolorization in liquid medium}

Three agar plugs of each fungus were inoculated in $20 \mathrm{~mL}$ of micronutrient liquid medium (without agar) in 100-mL Erlenmeyer flasks. Inoculated flasks were pre-incubated for seven days under static conditions at $25^{\circ} \mathrm{C}$. After pre-incubation, each inoculated flask was supplemented with 15,000 ppm coagulation residual black liquor or diluted black liquor wastewater. Furthermore, the best strain in fungi screening was used to decolorize original coagulation residual black liquor or black liquor wastewater. This wastewater was also used as a nutrient source. For determination adsorption ability, after growing in a liquid medium, thebest strain was autoclaved and then each inoculated flask was also supplemented with black liquor wastewater. The samples were collected periodically after 3,7 and 15,21 , and 30 days for measuring color, COD, and mycelial dry weight. After degradation time, samples were centrifuged to get supernatant that measured in the next experiment.

\subsection{Analytical methods}

The change in absorbance of black liquor was determined at $575 \mathrm{~nm}$ with a UV-Vis spectrophotometer (Optizen 2120 UV). Micronutrient medium only containing black liquor was used as a control. The percentage of decolorization was calculated as follows:

$$
\text { Decolorization }(\%)=\left(\frac{C c-C s}{C c}\right) x 100 \%
$$

where Ccis the initial dye concentration (ppm) and $C s$ is the final dye concentration (ppm).

COD analysis was performed by Standard Methods from APHA/AWWAWWEF ${ }^{(15)}$. The mycelial of fungus was separated from the medium using filter paper, and then dried at $55^{\circ} \mathrm{C}$ for $24 \mathrm{~h}$. The weight of mycelial on the filter was measured to determine the mycelial mass of fungus. The $\mathrm{pH}$ before and after degradation was measured by using the $\mathrm{pH}$ meter.

\subsection{Statistical analysis}

The ability comparison of Ceriperiopsis $s p$. and $P$. chrysosporium was conducted by using ANOVA with Tukey Simultaneous Test in the program MINITAB 17. The difference of average 
value (mean)was seen from Adjusted $P$-value in Tukey Test Simultaneous table with the level of confidence of $95 \%$.

\section{RESULTS AND DISCUSSION}

\subsection{Screening of fungi on agar and liquid media contaminated black liquor at 15,000 ppm}

A preliminary step on plates was carried out to determine the capacity of the fungal strains for black liquor decolorization. Among all the five strains tested, two fungihave the ability to grow more than $50 \%$ covering agar medium contaminated black liquor during five days (Figure 1). It means that these fungi have the potential to degrade lignin, and they can adapt to the pollutant. In liquid medium, Ceriporiopsissp demonstrated the highest capabilities for decolorizing black liquor than others. The initial decolorization was fast, reaching $60.4 \pm 1.43 \%$ on day 7. After that, there was a slower rate up to $30 \mathrm{~d}$, probably due to the depletion of glucose in the culture and the production of the enzymes for lignin degradation ${ }^{(4,16)}$.

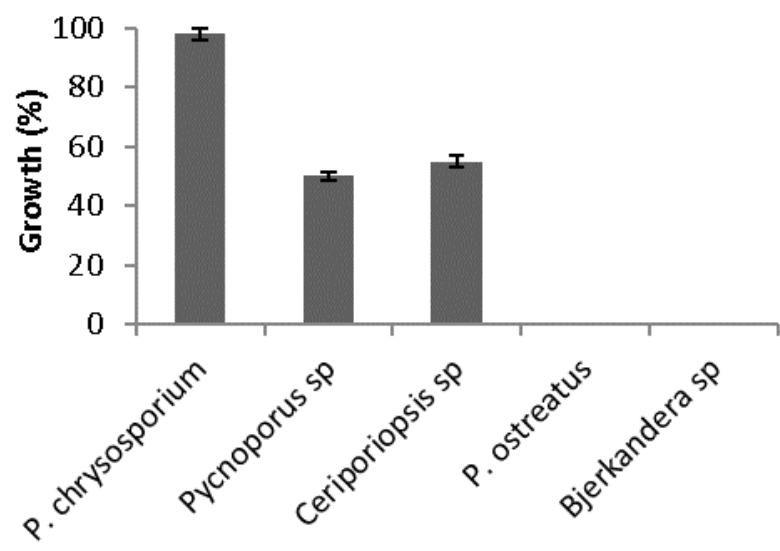

Fig. 1 Growth of fungi on agar medium contaminated black liquor

Fungal cultures were grown on the AG liquid phase and supplemented with black liquor.In the liquid medium, Ceriporiopsis sp demonstrated the higher capability for decolorizing black liquor than Phanerochaeta chrysosporium. The difference ability to degrade black liquor on agar and in liquid media was caused by the adaptation ability to decolorize black liquor and secretion of ligninolytic enzymes by fungi is different ${ }^{(17)}$.

Both fungi show the similar ability to decolorize coagulated black liquor. Ceriporiopsis sp. and $P$. chrysosporiumstarted the rapid decolorization of coagulated black liquor, by 74.89 and $72.42 \%$, respectively, at day 3(Fig.2). After that, from $15 \mathrm{~d}$, it was followed by a slower rate during the remaining period of incubation. Decolorization of black liquor was mostly affected by the fungal strain, the concentration of black liquor, and the carbon source.The slower changes in the decolorization of black liquor were due to the depletion of glucose as a nutrient source in the culture ${ }^{(4)}$. Trametes versicolor has able to detoxify and reduce the color of aromatic compounds and chemical oxygen demand (COD) from black liquors in a soda pulping mill. It reduced the color of aromatic compounds and COD of $70-80 \%$ and $60 \%$, respectively ${ }^{(18)}$. $T$. versicolor secreted laccase during degradation of black liquor. In the initial incubation, the decolorization of coagulated black liquor was higher than original black liquor. The small amounts of metals i.e. Aluminum, Cobalt, Copper can enhance the growth and enzyme activities of fungi ${ }^{(19)}$. However, each fungus has difference tolerance level for resistant with these metals. Aluminum can improve $\beta-1,4-N$ acetylglucosaminidase enzyme activity of Trichoderma fungi ${ }^{(19)}$. Furthermore, several extracellular enzymes remain active under metal concentrations.

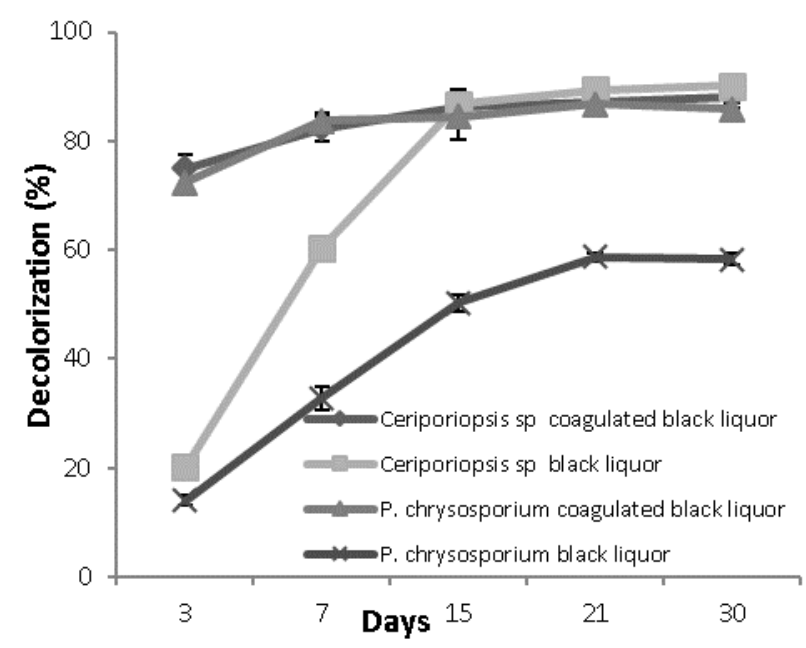

Fig. 2. Decolorization of $15,000 \mathrm{ppm}$ black liquor without and with coagulation by Ceriporiopsis $s p$. and $P$. chrysosporium

Ceriporiopsis sp. shows the higher ability to decolorize diluted black liquor than $P$. chrysosporium. A few publications reported the ability of this strain to degrade pollutant compounds. Ceriporiopsis subvermispora CZ-3 was able to decolorize black liquor, remove COD, and degrade lignin at glucose at $1 \mathrm{~g} / \mathrm{l}$ by $90 \%$, $45 \%$, and $62 \%$, respectively ${ }^{(20)}$. However, in the absence of glucose, this fungus only decolorized $62 \%$ of black liquor.Ceriporiopsis $s p$. is known as a genus of fungi in the family Phanerochaetaceae. This fungus produces manganese peroxidase $(\mathrm{MnP})$ andlaccase ${ }^{(21)}$. The ligninolytic enzymes i.e. lignin peroxidase 
(LiP), MnP, and laccase in WRF are known having the ability to degrade pollutant compounds. Based on the screening results, Cheriporiopsis sp. was selected for degradation of original black liquor wastewater in the liquid medium.

\subsection{Decolorization of original black liquorby Cheriporiopsis sp.}

In this experiment, original black liquor both with and without coagulation process was used. In our previous result, PAC $1 \%$ has able to decolorize original black liquor $98 \%$. This result was in line with Irfan et al. ${ }^{(22)}$ that PAC is excellent for color reduction. Coagulationflocculation method is one of the best options to treat black liquor wastewaterbecause it is cheaper than other methods such as membrane filtration and ozonation ${ }^{(22)}$. PAC is a prepolymerized $\mathrm{Al}(\mathrm{III})$ chemical, containing a range of hydrolysis and polymeric species. PAC may slow the rate of hydroxide precipitation, so this coagulant is useful for a longer time process, and more strongly adsorb at surfaces ${ }^{(23)}$. However, the high concentration of PAC lead to problems in solid-liquid separation of postprecipitation of $\mathrm{Al}$ and the large amount of coagulated sludge ${ }^{(24)}$.

Fig. 3 shows that Ceriporiopsis sp. has greater decolorizing of coagulated black liquor than original black liquor. In coagulation method, carboxylic and phenolic groups in black liquor wastewater reacted with metal cations of PAC ${ }^{(5)}$. Resultant compounds from coagulation process were degraded by Ceriporiopsis $s p$. It was assumed that this compound is easier to be degraded than black liquor compound because of its simple structure. WRF seem to be the most likely organisms to detoxify black liquor by degrading low molecular weight phenolic compounds, while increasing biodegradability due to the fractionation of high molecular weight compounds $^{(18)}$.

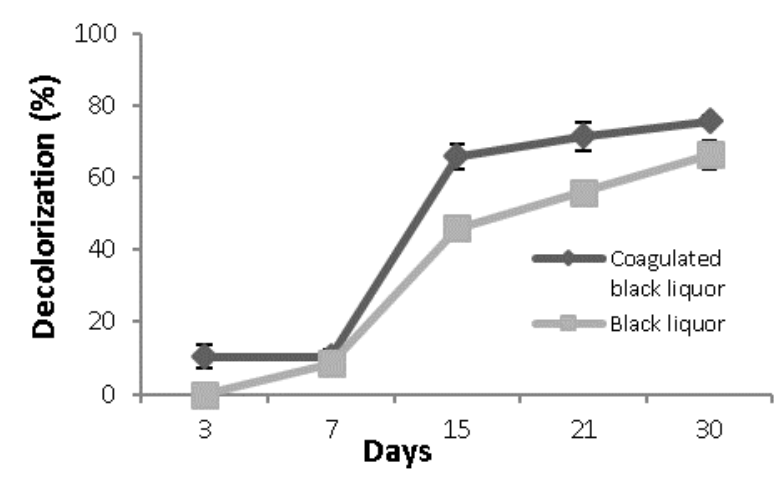

Fig. 3. Decolorization of original black liquor by Ceriperiopsis sp.
Based on the results of ANOVA, in all the incubation times, the decolorization of coagulated black liquor by using $\mathrm{P}$. chrysosporium $\mathrm{sp}$ and Ceriperiopsis $\mathrm{sp}$. was not significantly different. On the other hand, the decolorization of original black liquor by using $\mathrm{P}$. chrysosporium $\mathrm{sp}$ and Ceriperiopsis $\mathrm{sp}$. was significantly different. Therefore, from statistical analysis, it can be concluded that Ceriperiopsis $\mathrm{sp}$. has better decolorization of original black liquor level than $\mathrm{P}$. chrysosprium

Fig. 4 shows that PAC was effective coagulant to remove $\mathrm{COD}$ in black liquor wastewater. This removal could be enhanced by the addition of fungal treatment by Ceriporiopsis $s p$. Unfortunately, by only fungal treatment, COD removal was less than $30 \%$ at $30 \mathrm{~d}$ incubation. Inter-unit bonds in lignin are not hydrolyzable, so they are difficult to be biologically degraded. COD of removal can be increased if WRF secreted the higher enzyme activity. Enhancing enzyme activity could be done by addition of inducers, trace elements or carbon and nutrient source.

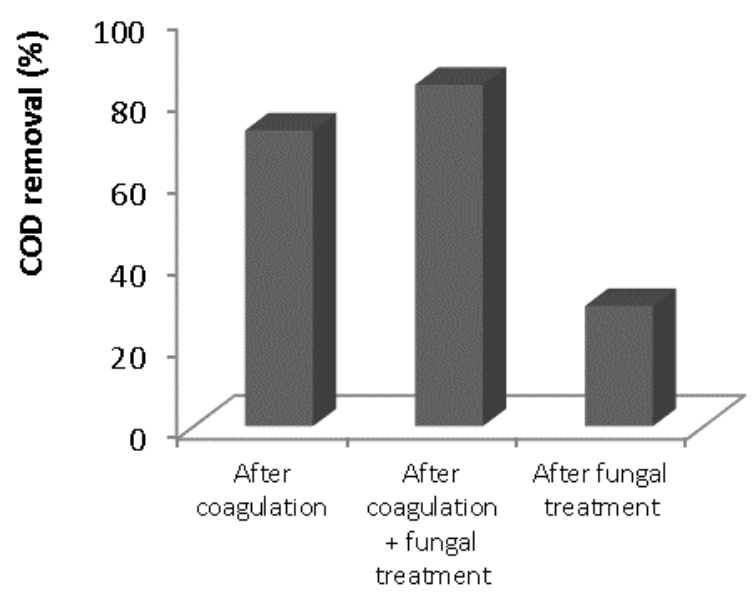

Fig. 4. COD removal in black liquor treatment

Fig. 5 shows that growth of Ceriporiopsis $s p$. was not affected by black liquor. It means that black liquor was not toxic for this strain. Lignin in black liquor was used as carbon source for growth of fungi. Furthermore, in line with the previous result from Kredics et al. ${ }^{(19)}$, aluminum enhanced the growth of fungi and Ceriporiopsis $s p$. has adaptation to heavy metal concentration in black liquor. Some microorganisms have difference tolerable rate to heavy metals depend on their ability to adsorb, bio-accumulate and transform metals ${ }^{(25)}$.Conidia produced by fungal strains growing in different heavy metal concentrations showed different morphological structure caused by resistance mutations ${ }^{(26)}$. The mycelial dry weight of Ceriporiopsis $s p$. without black liquor was similar with the mycelial dry 
weight of dead fungus cell contaminated black liquor, means adsorption did not play a role for this decolorization.

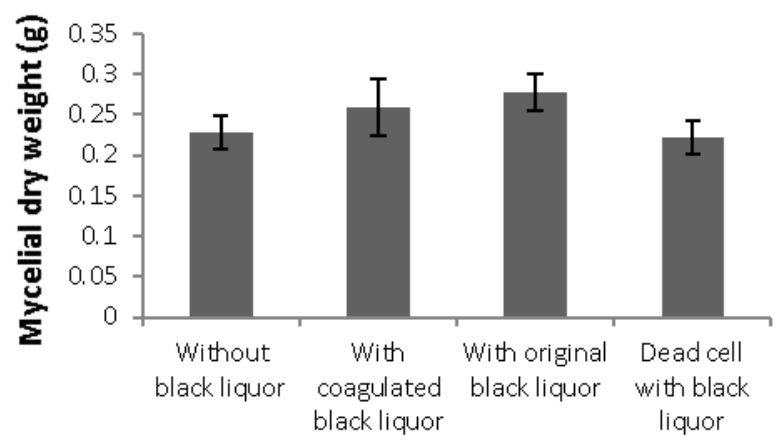

Fig. 5. Mycelial dry weight of Ceriperiopsis sp. at 30 days

We assumed two mechanisms might play roles for decolorization of black liquor by Ceriporiopsis sp.: pollutant was used as energy source and enzyme produced by WRF was secreted during limitation of glucose. This enzyme was used to attack black liquor ${ }^{(10)}$. The summary of coagulated black liquor removal is shown in Table 1.

Table 1. The removal of coagulated black liquor by Ceriperiopsis sp. on day 30

\begin{tabular}{lr}
\hline \multicolumn{1}{c}{ Parameter } & \multicolumn{1}{c}{ Values } \\
\hline Decolorization of black liquor & $75.57 \%$ \\
Degradation of lignin & $70.4 \%$ \\
COD & $83.35 \%$ \\
Mycelial dry weight & $0.26 \mathrm{gram}$ \\
Sludge weight after coagulation & $0.5 \mathrm{gram}$ \\
\hline
\end{tabular}

Ceriporiopsis sp. was found competent of reducing COD up to $83.4 \%$, black liquor up to $75.6 \%$, and lignin content up to $70.4 \%$ after $30 \mathrm{~d}$. The similar result between decolorization of black liquor and degradation of lignin showed that lignin was brokendown into other compounds. WRF are known having the capability to breakdown lignin with their extracellular enzymes i.e. lignin peroxidase, manganese peroxidase, and laccase. $P$. chrysosporium produces LiP and MnP corresponding to lignin degradation ${ }^{(27)}$. The presence of binding sites for oxidation of nonphenolic aromatics in the cases of LiP, and $\mathrm{Mn}^{2+}$ in the case of $\mathrm{MnP}$, respectively, are used to degrade lignin. The reaction of $\mathrm{MnP}$ with $\mathrm{b}$-aryl ether lignin model compounds is proceeded via a phenoxy radical intermediate, followed by $\mathrm{Ca}-\mathrm{Cb}$ bond cleavage, and also alkyl-phenyl bond cleavage reactions. On the other hand, the reaction of LiP with b-aryl ether lignin model compounds is proceeded via $\mathrm{Ca}-\mathrm{Cb}$ bond cleavage. Furthermore, due to its high redox potential, LiP can also oxidize nonphenolic methoxy-substituted lignin subunits. $P$. chrysosporium produced several metabolic products during degradation of lignin such as benzoic acid, benzaldehyde, cinnamic acid, biphenyl-5-5'-dicarboxylic acid, 2,2'-dihydroxy, 3,3'-dimethoxy, and diphenyl ether ${ }^{(28)}$. However, metabolic products of lignin during degradation of black liquor by Ceriperiopsis sp. still needs further investigation.

Decolorization by WRF is not much impressive in reducing color but reduction in BOD and COD has been found to be much satisfactory $^{(29)}$.The advantages of the biological treatment are no sludge and less toxic because enzyme activity produced by fungi can break down the structure of black liquor. Unfortunately, a very limited experience is available on the possibility of direct degradation of highly contaminant black liquor by WRF.

\section{CONCLUSIONS}

Ceriporiopsis sp. showed the ability to grow more than $50 \%$ on agar medium. In liquid medium, this strain decolorized $15,000 \mathrm{ppm}$ coagulated and diluted black liquor by approximately $90 \%$ at 30 days. Further, the color of original and coagulated black liquor can be decolorized up to 90.13 and $86.85 \%$, respectively. COD in original and coagulated black liquor was reduced up to 70.17 and $40.09 \%$, respectively. The result showed Ceriporiopsis $s p$ has a potential alternative to treat black liquor wastewater. By using combination treatment coagulation-fungal treatment, we obtained several advantages such as high decolorization and COD removal, less sludge comparing with only coagulation method by PAC 5\%, and less toxic because lignin compound is breakdown. Finally, coagulationWRF systems are presented in this work as a promising efficient alternative for the treatment of black liquor. Further, to make efficient, this strain can be optimized by immobilization system in an aerated reactor, completed with fluidized, stirred, and air-pulsed reactors.

\section{REFERENCES}

1. Wiloso, E.I., Heijungs, R., Snoo G.R.d., (2012), LCA of Second Generation Bioethanol: A Review and Some Issues to be Resolved for Good LCA Practice, Renew Sust Energ Rev, 16(7): 5295-5308.

2. Sari, A.A., Tachibana, S., Limin, S.G., (2013), Enhancement of Ligninolytic Activity of Trametes versicolor U97 Pre-grown in 
Agricultural Residues to Degrade DDT in Soil, Water Air Soil Poll 224(7): 1-9.

3. Bugg, T.D.H., Ahmad, M., Hardiman, E.M., Singh, R., (2011), The Emerging Role for Bacteria in Lignin Degradation and Bioproduct Formation, Curr Opin Chem Biol, 22: 394-400.

4. Wu, J., Xiao, Y.Zhong., Yu, H.Q., (2005), Degradation of Lignin in Pulp Mill Wastewaters by White-Rot Fungi on Biofilm. Bioresource Technol, 96: 1357-1363.

5. Sari, A. A., Kurniawan, H. H., Nurdin, M., Abimanyu, H., (2015), Decolorization of Black Liquor Wastewater Generated from Bioethanol Process by Using Oil Palm Empty Fruit Bunches. Energy Procedia, 68: 254262.

6. Hossain, K., Ismail, N., (2015), Bioremediation and Detoxification of Pulp and Paper Mill Effluent: A Review. Research Journal of Environmental Toxicology, 9: 113134.

7. Pokhrel, D., Viraraghavan, T., (2004), Treatment of Pulp and Paper Mill Wastewater-a Review. Sci. Total Environ,333(1): 37-58.

8. Rodrigues, A.C., Boroski, M., Shimada, N.S., Garcia, C., Nozaki, J., Hioka, N., (2008), Treatment of PaperPulp and PaperMill Wastewater by Coagulation-Flocculation Followed by Heterogeneous Photoctalysis. J Photochem Photobiol A, 194: 1-10.

9. Hermosilla, D., Merayo, N., Gasco, A., Blanco, A., (2015), The application of advanced oxidation technologies to the treatment of effluents from the pulp and paper industry: a review. Environ SciPollut Res Int. 22(1): 168-191.

10. Sari, A.A., Tachibana, S., Muryanto, (2012), Correlation of Ligninolytic Enzymes from the Newly-Found Species Trametesversicolor U97 with RBBR Decolorization and DDT Degradation.Water Air Soil Poll, 223(9):57815792.

11. Mehna, A., Bajpai, P., Bajpai, P.K., (1995), Studies on Decolorization of Effluent from a Small PulpMill UtilizingAgriresidues with Trametesversicolor. Enzyme Microb Tech, 17(1): 18-22.

12. Lara, M.A., Rodriguez-Malaver, A.J., Rojas, O.J., Holmquist, O., Gonzalez, A.M., Bullon, J., Penaloza, N., Araujo, E. (2003), Black Liquor Lignin Biodegradation by Trametes elegans. Int Biodeter \& Biodeg, 52: 167-173.
13. Re, V.D., Papinutti, L.,(2011), Black LiquorDecolorization by Selected WhiteRotFungi.ApplBiochem and Biotech, 165(2): 406-415.

14. Saratale, R.G., Saratale, G.D., Chang, J.S., Govindwar, (2009), Ecofriendly Degradation of SulfonaedDiazoDye C.I. Reactive Green 19A using Micrococcus glutamicus NCIM2168. BioresTechnol, 100: 3897-3905.

15. APHA-AWWA-WEF. (2005), Standard Methods for the Examination of Water and Wastewater. 21st ed. New York: American Publishing Health Association, American Water Works Association and Water Environment Federation.

16. Hossain, K., Ismail., N., (2015), Bioremediation and detoxification of pulp and paper mill effluent: A review. Research Journal of Environment Toxicology, 9(3): 113-134.

17. Tekere, M., Mswaka, A.Y., Zvauya, R., Read, J.S., (2001), Growth, dye degradation and ligninolytic activity studies on Zimbabwean white rot fungi. Enzyme and Microbial Technology, 28: 420-426.

18. Font, X., Caminal, G., Gabarrell, X., Romero, S., Vicent, MT., (2003), Black Liquor Detoxification by Laccase of Trametes versicolor pellets. J Chem Technol and Biotechnol, 78: 548-554.

19. Kredics, L., Doczi, I., Antal, Z., Manczinger, L., (2001), Effect of Heavy Metals on Growth and Extracellular Enzyme Activities of Mycoparasitic Trichoderma Strains. Bull Environ Contam Toxicol., 66: 249-254.

20. Nagarathnamma, R., Bajpai, P., Bajpai, P.K., (1999), Studies on Decolourization, Degradation and Detoxification of Chlorinated Lignin Compounds in Kraft Bleaching Effluents by Ceriporiopsis subvermispora. Process Biochemistry, 34: 939-948.

21. Ruttimann, C., Schwember, E., Salas, L., Cullen, D.,Vicuiia, R., (1992), Ligninolytic Enzymes of the White-rot Basidiomycetes Phlebiabrevispora and Ceriporiopsis subvermispora. Biotechnol Appl Biochem. 16: 64-76.

22. Irfan, M., Butt, T., Imtiaz, N., Abbas, N., Khan, R.A., Shafique, A.,(2013), The Removal of COD, TSS and Colour of Black Liquor by Coagulation-FlocculationProcess at Optimized $\mathrm{pH}$, Settling and DosingRate. Arabian Journal of Chemistry. http://dx.doi.org/10.1016/j.arabjc.2013.08.007 
23. Sanghi, R., Bhattacharya, B., Dixit, A., Singh, V.,(2006), Ipomoea dasyspermaSeed Gum: An Effective Natural Coagulant for the Decolorization of Textile Dye Solutions. Journal of Environmental Management. 81:36-41.

24. Yang, Z., Gao, B., Yue, Q., (2010), Coagulation performance and residual aluminum speciation of $\mathrm{Al}_{2}\left(\mathrm{SO}_{4}\right)_{3}$ and polyaluminum chloride (PAC) in Yellow River water treatment. Chemical Engineering Journal, 165: 122-132.

25. Ferreira, V., Goncalves, A.L., Pratas J., Canhoto, C., (2010), Contamination by Uranium Mine Drainages Affects Fungal Growth and Interactions between Fungal Species and Strains. Mycologia, 102 (5): 1004-1011.

26. Braha, B., Tintemann, H., Krauss, G., Ehrman, J., Barlocher, F., Krauss, G.J.,(2007), Stress Response in Two Strains of the Aquatic Hyphomycete Heliscuslugdunensis after exposure to cadmium and copper ions. Bio Metals, 20:93- 105

27. Cameron, M.D., Timofeevski, S., Aust, S.D., (2000), Enzymology of Phanerochaete chrysosporium with Respect to the Degradation of Recalcitrant Compounds and Xenobiotics. Appl Microbiol Biotechnol, 54: 751-758.

28. Bugg, T.D.H., Ahmad, M., Hardiman, E.M., Rahmanpor, R., (2011), Pathways for Degradation of Lignin in Bacteria and Fungi, Nat. Prod. Rep., 28: 1883-1896.

29. Cecen, F., Urban, W., Haberl, R., (1992), Biological and Advanced Treatment of Sulfate Pulp Bleaching Effluents. Water Sci. Technol. 26(1-2): 435-444. 